\title{
ARTIKKELIT
}

\section{ע Ikääntyvien näkemyksiä sosiaali- ja terveydenhuollon sähköisistä palveluista}

\author{
Jukka Mielonen ${ }^{1}$, Kaija Saranto ${ }^{1}$, Hanna Kuusisto ${ }^{1,2}$, \\ Anssi Kemppi ${ }^{3}$, Ulla-Mari Kinnunen ${ }^{1}$ \\ ${ }^{1}$ Sosiaali-ja terveysjohtamisen laitos, Itä-Suomen yliopisto \\ ${ }^{2}$ Tampereen yliopistollinen sairaala \\ ${ }^{3}$ Eläkeliitto ry
}

\begin{abstract}
Väestön ikääntyminen uhkaa kasvattaa sosiaali- ja terveydenhuoltokuluja. Aiempien tutkimusten mukaan ikääntyvän väestön selviytyminen sosiaali- ja terveydenhuollon palveluiden sähköistymisestä on epävarmaa. Tämän tutkimuksen tarkoituksena oli kuvata 65 vuotta täyttäneiden suomalaisten valmiutta ja halua käyttää sosiaali- ja terveydenhuollon sähköisiä palveluita ja niihin liittyvää tietotekniikkaa sekä lääkinnällisiä laitteita ja tietojärjestelmiä. Tutkimus toteutettiin keväällä 2019 verkkokyselynä. Aineiston validoinnin jälkeen otoskoko oli 978. Viitekehyksenä käytettiin UTAUT (Unified Theory of Technology Acceptance) -mallia. Tutkimusaineisto analysoitiin kvantitatiivisella tilastoanalyysillä ja induktiivisella sisällönanalyysillä. Kyselyyn vastanneilla 65-74-vuotiailla on hyvät tietotekniset taidot, tarvittavat laitteet sekä halukkuus käyttää sosiaali- ja terveydenhuollon sähköisiä palveluita. Yli 75-vuotiaat kokevat tietotekniset taitonsa välttäviksi tai huonoiksi. Suurin osa vastanneista käytti tietotekniikkaa tai älylaitetta kotonaan pankkipalveluihin ja uutisten lukemiseen sekä sosiaali- ja terveydenhuollon palveluihin. Enemmistö oli käyttänyt sähköisiä sosiaali- ja terveydenhuollon palveluita ainakin joskus. Sosiaali- ja terveydenhuollon ammattilaisten tulee ohjata väestöä aiempaa aktiivisemmin sähköisten palveluiden piiriin. Palveluverkkojen suunnittelussa on otettava huomioon ikääntyvän väestön kyky käyttää sähköisiä palveluita.
\end{abstract}

\section{Johdanto}

Ensimmäiset tietokoneet tulivat suomalaisiin kotitalouksiin 1980-luvulla. Kotimikrojen ja modeemien yleistymisen myötä internetin käyttö alkoi lisääntymään 1990-luvulla (Saarikoski 2014). Vaikka laitteiden määrä kotitalouksissa kasvoi, eläkeikäiset henkilöt eivät ole niitä välttämättä kotiinsa hankkineet. Ikääntyvän väestön tietotekniikan tai internetpalveluiden käyttö ei ole siis itsestään selvää. Sosiaalija terveysministeriön Sote-tieto hyötykäyttöön -strategian yhtenä tavoitteena on lisätä kansalaisten aktiivisuutta omahoidossa (Seppälä \& Puranen 2015). Rinteen (2019) hallitusohjelmassa oli linjattu hyvinvointi- ja terveyserojen 
kaventaminen sekä yhdenvertaisten ja laadukkaiden palveluiden turvaaminen. Tämä herättää kysymyksen, kuinka vanheneva väestö pysyy muutoksessa mukana sosiaali- ja terveyspalveluiden muuttuessa yhä enemmän sähköisiksi (Hyppönen \& Ilmarinen 2016; Kauppila ym. 2018).

Ikääntyvillä henkilöillä on todettu olevan haasteita terveysteknologian käytössä. Erityisesti he, jotka eniten hyötyisivät sähköisen sairauskertomuksen käytöstä, eivät sitä pysty käyttämään, koska heillä on havaittu olevan puutteelliset tietotekniikan ja internetin käyttötaidot, teknologiapelkoa sekä fyysisiä ja kognitiivisia rajoitteita (Kim ym. 2009). Myös itse tietokone tai älypuhelin laitteena on ikääntyvän väestön näkemyksen mukaan hankalakäyttöinen (Goodall ym. 2014; Lind \& Karlsson 2014). Ikääntyvien oppimis- ja omaksumiskyvyt ovat kuitenkin hyvät, joten erilaiset räätälöidyt digitaaliset ratkaisut saattaisivat lisätä muun muassa internetin käyttöä ikääntyvän väestön keskuudessa (Lind \& Karlsson 2014).

OECD:n (2001) määrityksen mukaan termillä "digitaalinen kuilu" tarkoitetaan kansalaisten yhdenvertaista mahdollisuutta päästä käyttämään laajasti tele- ja viestintäteknologiaa. Yksilöiden, kotitalouksien, talousalueiden tai maantieteellisten alueiden välillä voi olla eroja eri sosioekonomisilla tasoilla. Suomessa lisääntyneiden sähköisten palveluiden on havaittu suurentavan digitaalista kuilua eri käyttäjäryhmien välillä. Digitaalista kuilua muodostavat muun muassa maantieteelliset ja yksilölliset tekijät, kuten laitteiston hankkimiseen liittyvät taloudelliset tekijät ja internetyhteyksien saatavuus. (Rasmus 2010.)

Ikä ei kiistatta selitä sähköisten palveluiden vähäistä käyttöä. Tuoreen suomalaisen tutkimuksen mukaan vuonna 2017 sähköisiä palveluita käytti 68 prosenttia vastaajista ja käyttö oli yleistynyt vuoteen 2014 verrattuna. Käyttöä lisääviä tekijöitä olivat pitkäaikaissairaus, hyvä digipalveluiden käytön osaaminen, korkea koulutus, positiivinen asenne, mahdollisuus käyttää palveluita, palveluiden saatavuus ja asuin- alue. Toisaalta osaamisen tason itsearvioinnissa 69 prosenttia yli 75-vuotiaista arvioi, että ei osaa käyttää sähköisiä palveluita. (Hyppönen ym. 2018a.) Joidenkin tutkimusten mukaan iällä on kuitenkin merkittävä vaikutus sähköisten palveluiden käyttöön. Raporttien mukaan iäkkäämmillä ihmisillä ei ole välineitä tai tarvittavia taitoja käyttää sähköisiä palveluita. (Reiners ym. 2019.)

Tiedetään, että suorituskyvyllä, vaivattomuudella, sosiaalisella vaikutuksella, teknologia-ahdistuksella ja muutosvastarinnalla on merkittävä vaikutus aikomukseen käyttää terveydenhuollon mobiilisovelluksia. Mahdollistavilla olosuhteilla ja aikomuksella ei näytä olevan merkittävää riippuvuutta käyttöön (Hogue \& Sorwar 2017). Edellä mainituista käyttöönottoon vaikuttavista tekijöistä mahdollistavat olosuhteet, suorituskyky ja vaivattomuus ovat teknologialähtöisiä tekijöitä,joissa järjestelmän tai laitteen toiminta vaikuttaa henkilön kokemukseen uuden teknologian käytöstä. Sen sijaan sosiaalinen vaikutus, teknologia-ahdistus ja muutosvastarinta ovat henkilön subjektiivisia kokemuksia. WWW-sivustojen käyttöliittymien toteutukseen liittyvässä tutkimuksessa (Mantere 2001) on todettu, että WWW-käyttöliittymiä ei ole syytä suunnitella ikääntyvää väestöä varten toisenlaiseksi kuin muille ikäryhmille. Tutkimukseen osallistuneet eivät pitäneet itseään erityisryhmänä, joka tarvitsisi erilaisia käyttöliittymiä. Käyttöliittymien suunnittelussa olisi otettava huomioon ikääntymisen vaikutukset, näkövammaisuus ja liikuntaesteet. Sivustoilla pitäisi olla selkeä rakenne, ja sivustoilla navigoinnin tulisi olla helppoa.

Vuonna 2018 tehdyn kirjallisuuskatsauksen mukaan ikääntyvä väestö on syytä huomioida sekä teknologiaa että järjestelmä- ja sovellusratkaisuja suunniteltaessa (Rosenlund \& Kinnunen 2018). Myös ammattilaiset tarvitsevat koulutusta ja opastusta potilaiden ohjaamisessa sähköisten palveluiden piiriin. Ammattilaisten on havaittu arvioivan tietotekniset taitonsa hyviksi, mutta siitä huolimatta he kokevat epävarmuutta opastaessaan ja motivoidessaan potilai- 
ta sähköisten palveluiden käyttöön (Kujala ym. 2018). Tätä havaintoa tukevat myös tutkimukset, joissa todetaan, että ammattilaiset saavat liian vähän koulutusta uusien toimintatapojen muutoksiin tai kohtaavat vaikeuksia sähköisissä toimintatavoissa (Hyppönen ym. 2018b; Kinnunen ym. 2019).

Tutkimuksemme perustuuUTAUT (Unified Theory of Technology Acceptance) -teoriaan. Teoria perustuu tutkimukseen, jossa on vertailtu kahdeksaa eri teknologian hyväksymiseen liittyvää mallia (Theory of Reasoned Action, Technology Acceptance Model, Motivational Model, Theory of Planned Behavior, yhdistetty malli: Technology Acceptance Model ja Theory of Planned Behavior, Model of PC Utilization, Innovation Diffusion Theory sekä Social Cognitive Theory) sekä niiden laajennuksia. Tutkimus toteutettiin neljässä organisaatiossa kuuden kuukauden aikana. Tulosten perusteella muodostettiin UTAUTmalli, jota testattiin alkuperäisellä aineistolla. Malli vahvistettiin testaamalla sitä kahdessa organisaatiossa. UTAUT-mallin mukaan uuden teknologian käyttöönottoon vaikuttavia tekijöitä ovat suorituskykyodotukset, vaivattomuusodotukset, sosiaalinen vaikutus ja mahdollistavat olosuhteet. Mallin on todettu olevan hyvä työväline arvioitaessa uuden teknologian käyttöönoton todennäköisyyttä ja pyrittäessä ymmärtämään hyväksynnän tekijöitä. Hyväksynnän tekijöiden ymmärtämisen avulla voidaan kohdejoukolle, johon kuuluvat henkilöt epätodennäköisimmin omaksuvat ja käyttävät uutta teknologiaa, kohdistaa oikeanlaisia toimia (esim. koulutusta) (Venkatesh ym.2003). Aiemmissa tutkimuksissa malli on osoitettu hyvin toimivaksi (Wills ym. 2008; Kijsanayotin ym. 2009).

Tämän tutkimuksen tarkoituksena on selvittää 65 vuotta täyttäneiden henkilöiden valmiutta ja halukkuutta käyttää sosiaali- ja terveydenhuollon sähköisiä palveluita Suomessa. Tässä tutkimuksessa sähköisillä palveluilla tarkoitetaan muun muassa internetin välityksellä toimivaa etäasiointia, Kelan palveluita ja itsehoitopalveluita.

\section{Tutkimusmenetelmät ja aineisto}

Tämän kvantitatiivisen tutkimuksen kohderyhmänä ovat 65 vuotta täyttäneet henkilöt Suomessa. Tilastokeskuksen (2019) mukaan Suomessa oli vuoden 2018 lopussa 65 vuotta täyttäneitä henkilöitä noin 1,2 miljoonaa, eli noin 22 prosenttia väestöstä. Tutkimuksen tarkoituksena on kuvata ikääntyvän väestön valmiutta ja halukkuutta käyttää sosiaali- ja terveydenhuollon sähköisiä palveluita ja niihin liittyvää tietotekniikkaa sekä lääkinnällisiä laitteita ja tietojärjestelmiä. Tässä tutkimuksessa sähköisillä sosiaali- ja terveydenhuollon palveluilla tarkoitetaan Omakanta-, ajanvaraus- tai omahoitopalveluita tai Kelan palveluita.

Tutkimuskysymykset:

1. Mikä on 65 vuotta täyttäneiden kansalaisten valmius sosiaali- ja terveydenhuollon sähköisten palveluiden käyttöön?

2. Mikä kannustaa 65 vuotta täyttäneitä kansalaisia ottamaan käyttöön tai estää heitä ottamasta käyttöön sosiaali- ja terveydenhuollon sähköisiä palveluita?

Kyselylomake muodostettiin operationalisoimalla UTAUT (Unified Theory of Technology Acceptance) -teorian muuttujia (Venkatesh ym. 2003). Kysymyksiä oli yhteensä 39, ja niistä avoimia kysymyksiä oli kaksi. Kyselylomake toteutettiin Eduix E -lomakkeella. Kysymysten vastausvaihtoehdot olivat "kyllä" ja "ei" (osaan vastauksista pyydettiin lisätietoja tekstikentällä), monivalintoja sekä Likert-asteikon (hyvin usein - en koskaan tai täysin samaa mieltä en osaa sanoa) väittämiä. Osaa kysymyksistä ei näytetty vastaajalle, mikäli sitä edeltävä arvo ei täyttynyt lomakkeella. Tällaisia arvoja olivat muun muassa sairaus ja sairauden hoitoon käytettävä laite (Valvira 2017).

Tutkimuksen tiedote ja kyselylomakkeen linkki lähetettiin Eläkeliitto ry:n jäsenille sähköpostitse. Vanhustyön keskusliitto markkinoi tutkimusta omilla SeniorSurf-toiminnan verkkosivuillaan. Tutkimusta markkinoitiin myös sosiaalisessa mediassa, verkkosivustoilla ja eri 
julkaisualustoilla (esim. LinkedIn ja Facebook). Tutkimukseen oli mahdollista vastata avustettuna, mikäli vastaaja ei itse kyennyt avaamaan kyselyä. Vastausaikaa oli noin 3 kuukautta.

Tutkimusaineisto analysoitiin IBM SPSS Statistic 25- ja 26-ohjelmilla. Aineistosta laskettiin sekä sosiodemografiset että sairauksiin liittyvät suhdeluvut. Analysointivaiheessa Likertasteikollisia vastauksia luokiteltiin uudelleen. Khiin neliö -testin avulla tarkasteltiin taustamuuttujien tilastollista riippuvuutta tutkittaviin muuttujiin, ja Pearsonin korrelaatiokertoimen avulla tarkasteltiin muuttujien välisiä yhteyksiä. Aineistosta muodostettiin taulukoita Microsoft Excel -taulukkolaskentaohjelmalla. Avoimet vastaukset analysoitiin induktiivisella sisällönanalyysillä. Sisällönanalyysissä avoimet vastaukset pelkistettiin ja ryhmiteltiin kuvaavien ilmaisujen avulla pääluokiksi. Pääluokista laskettiin raportoitavat tilastot.

\section{Tulokset}

Vastauksia tuli 1020 kpl, joista hylättiin 42 virheellisen iän (ikä alle 65 vuotta tai yli 110 vuotta) tai puuttuvien tietojen vuoksi. Otoskooksi muodostui siten 978 vastausta $(\mathrm{n}=978)$. Vastaajien ikä oli 65-90 vuotta (ka. 71 vuotta). Vastaajien taustatiedot on esitetty taulukossa 1.

Suurimalla osalla vastaajista (92\%) oli tar- vittavat välineet sähköisten palveluiden käyttöön kaikissa ikäluokissa (65-74 v., 75-84 v. ja $\geq 85$ v.). Vastaajat käyttivät tietotekniikkaa muun muassa pankkipalveluihin ja uutisten lukemiseen sekä sosiaali- ja terveydenhuollon palveluihin. Suurin osa 65-74-vuotiaista koki tietotekniset taitonsa hyviksi (64 \%), mutta yli 74-vuotiaista 53 prosenttia koki taitonsa vältättäviksi ja 2 prosenttia huonoiksi. Tietotekniset taidot näyttäisivät heikkenevän iän kasvaessa. Tulokset välineistä, tietoteknisistä taidoista ja palveluiden käytöstä on esitelty taulukossa 2 .

Suurimmalla osalla kyselyyn vastanneista (68 \%) oli käytössä sairauden diagnosointiin, ehkäisyyn, tarkkailuun, hoitoon tai lievitykseen tarkoitettu laite tai sovellus (esim. verenpainetai verensokerimittari). Vastaajista 13 prosentilla oli vamman tai vajavuuden diagnosointiin, tarkkailuun, hoitoon, lievitykseen tai kompensointiin (esim. sydämen tahdistin) ja 4 prosentilla anatomian tai fysiologisen toiminnon tutkimiseen, korvaamiseen tai muunteluun (esim. spirometri) tarkoitettu laite. Vastaajista 15 prosenttia ei osannut kertoa, mitä varten laite tai sovellus oli käytössä. Tutkittavista suurin osa (82\%) luotti laitteen tai sovelluksen toimintaan - myös kaikissa ikäluokissa. Tietoteknisen laitteen tai sovelluksen käytön esteeksi koettiin muun muassa vaikeatajuinen teksti tai laitteen monimutkaisuus. Tietoteknisen laitteen tai sovelluksen käytön esteitä on esitelty kuviossa 1.

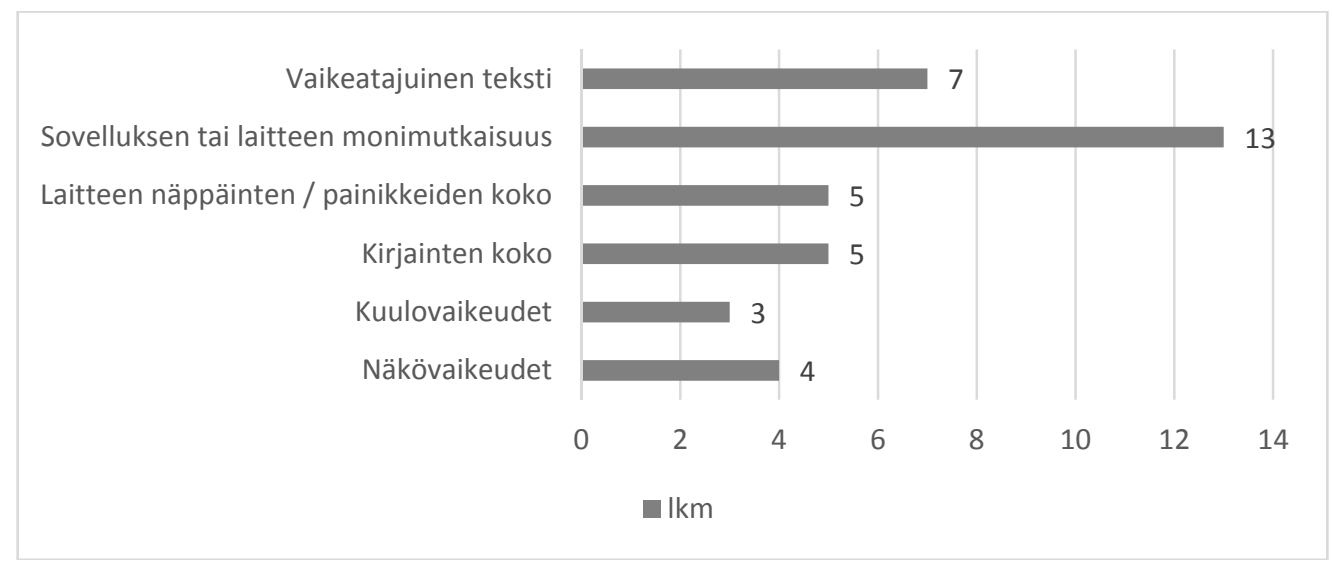

Kuvio 1. Tietoteknisen laitteen tai sovelluksen käytön esteet $(n=37)$. 
Taulukko 1. Vastaajien taustatiedot $(n=978)$.

\begin{tabular}{|c|c|c|c|}
\hline Kysymys & Vastausvaihtoehdot & $\mathrm{lkm}$ & $\%$ \\
\hline \multirow[t]{2}{*}{ Sukupuoli } & nainen & 648 & 66,7 \\
\hline & mies & 323 & 33,3 \\
\hline \multirow[t]{5}{*}{ Työssäolo } & työssä & 9 & 0,9 \\
\hline & osa-aikaeläkkeellä & 1 & 0,1 \\
\hline & osatyökyvyttömyyseläkkeellä & 1 & 0,1 \\
\hline & työkyvyttömyyseläkkeellä & 11 & 1,1 \\
\hline & vanhuuseläkkeellä & 949 & 97,7 \\
\hline \multirow[t]{4}{*}{ Kotikunnan koko (asukasluku) } & $<10000$ & 392 & 40,1 \\
\hline & $10000-49999$ & 305 & 31,2 \\
\hline & $50000-100000$ & 138 & 14,1 \\
\hline & $>100000$ & 143 & 14,6 \\
\hline \multirow[t]{2}{*}{ Kyselyyn vastaaminen } & itsenäisesti & 964 & 98,7 \\
\hline & avustettuna & 13 & 1,3 \\
\hline \multirow[t]{6}{*}{ Kotitalouden bruttotulot } & $500-999 €$ & 12 & 1,2 \\
\hline & $1000-1499 €$ & 90 & 9,3 \\
\hline & $1500-1999 €$ & 107 & 11,1 \\
\hline & $2000-2499 €$ & 181 & 18,7 \\
\hline & $2500-2999 €$ & 143 & 14,0 \\
\hline & $>3000 €$ & 435 & 44,9 \\
\hline \multirow[t]{7}{*}{ Koulutustaso } & vähemmän kuin peruskoulun ala-aste tai vastaava & 8 & 0,8 \\
\hline & peruskoulun ala-aste (1.-6. luokat), kansakoulu & 109 & 11,2 \\
\hline & peruskoulun yläaste (7.-9./10. luokat), keskikoulu & 124 & 12,7 \\
\hline & lukio, ylioppilastutkinto tai ammatillinen tutkinto & 283 & 29,0 \\
\hline & opisto- tai korkeakoulututkinto & 422 & 43,3 \\
\hline & lisensiaatin tai tohtorin tutkinto & 17 & 1,7 \\
\hline & ei mitään näistä & 12 & 1,2 \\
\hline \multirow[t]{3}{*}{ Asumismuoto } & yksin omassa kodissa & 291 & 30,1 \\
\hline & yhdessä jonkun kanssa & 675 & 69,7 \\
\hline & palvelukodissa/vanhainkodissa tai vastaavassa & 2 & 0,2 \\
\hline \multirow[t]{3}{*}{ Tietotekniset taidot } & hyvä & 581 & 59,4 \\
\hline & välttävä & 373 & 38,1 \\
\hline & huono & 24 & 2,5 \\
\hline \multirow[t]{2}{*}{ Ajokortti ja käytössä oleva auto } & kyllä & 876 & 90,2 \\
\hline & ei & 95 & 9,8 \\
\hline
\end{tabular}

Vastaajat etsivät tietoa sähköisesti eniten terveyspalveluista (66\%), sairauksista (58\%) ja liikunnasta (53\%). Myös terveyden edistämisestä (52\%) ja ruokavaliosta (43\%) etsittiin tietoa. Vastaajista 32 prosenttia etsi tietoa sosiaalivakuutuksista (esim. Kelan etuudet) ja 32 prosenttia sosiaalipalveluista. Vastaajista 8 prosenttia ilmoitti, etteivät he etsi tietoa säh- köisesti. Vastaajista 27 prosenttia kertoi hakevansa sairauteen liittyvää lisätietoa, ja heistä suurin osa oli naisia (76\%). Khiin neliö -testin mukaan sukupuoli vaikuttaa tilastollisesti merkitsevästi lisätietojen hakuun: $\mathrm{df}=1$; $\mathrm{X}^{2}(2)=5,255 ; \mathrm{p}=0,022$. Kotikunnan koolla oli myös vaikutusta lisätietojen hakuun. Alle 50000 asukkaan kunnissa asuvat hakivat lisä- 
Taulukko 2. Välineet sähköisten palveluiden käyttöön ja palveluiden käyttötarkoitus ( $n=978)$.

\begin{tabular}{|c|c|c|c|}
\hline Välineet ja tietotekniikan käyttö & Vastausvaihtoehdot & $\mathrm{lkm}$ & $\%$ \\
\hline $\begin{array}{l}\text { Tarvittavat välineet sähköisten } \\
\text { palveluiden käyttöön } \\
\text { (luokiteltu) }\end{array}$ & $\begin{array}{l}\text { kyllä } \\
\text { ei }\end{array}$ & $\begin{array}{c}880 \\
60\end{array}$ & $\begin{array}{c}92,3 \\
6,3\end{array}$ \\
\hline \multirow[t]{3}{*}{ Laitteiden käyttöympäristö } & $\begin{array}{l}\text { tietokonetta kotona } \\
\text { tietokonetta muvalla }\end{array}$ & $\begin{array}{c}690 \\
6\end{array}$ & $\begin{array}{c}70,8 \\
0,6\end{array}$ \\
\hline & älylaitetta (puhelin tai tablettilaite) kotona & 248 & 25,4 \\
\hline & älylaitetta (puhelin tai tablettilaite) muvalla & 24 & 2,5 \\
\hline \multirow[t]{9}{*}{ Tietotekniikan käyttö } & pankkipalveluihin & 937 & 95,8 \\
\hline & uutisten lukemiseen & 781 & 79,9 \\
\hline & julkisen hallinnon palveluihin (esim. Kela, Vero ja Poliisi) & 770 & 78,7 \\
\hline & sosiaali- ja terveydenhuollon palveluihin & 743 & 76,0 \\
\hline & ajanvietteeksi & 727 & 74,3 \\
\hline & harrastuksiin & 581 & 59,4 \\
\hline & matkailutarkoituksiin & 552 & 56,4 \\
\hline & sairauteen liittyvään tiedon hakuun & 490 & 50,1 \\
\hline & en käytä ollenkaan tietotekniikkaa & 7 & 0,7 \\
\hline \multicolumn{4}{|l|}{ Tietotekniset taidot } \\
\hline \multirow[t]{3}{*}{ 65-74-vuotiaat } & hyvä & 487 & 63,7 \\
\hline & välttävä & 261 & 34,1 \\
\hline & huono & 17 & 2,2 \\
\hline \multirow[t]{3}{*}{ 75-84-vuotiaat } & hyvä & 93 & 44,9 \\
\hline & välttävä & 109 & 52,7 \\
\hline & huono & 5 & 2,4 \\
\hline \multirow[t]{3}{*}{$\geq 85$-vuotiaat } & hyvä & 1 & 16,7 \\
\hline & välttävä & 3 & 50,0 \\
\hline & huono & 2 & 33,3 \\
\hline
\end{tabular}

tietoja enemmän verrattuna yli 50000 asukkaan kunnissa asuviin. Näiden välillä havaittiin Khiin neliö -testin mukaan tilastollisesti merkitsevä ero: $\mathrm{df}=1 ; \mathrm{X}^{2}(2)=4,062 ; \mathrm{p}=0,044$.

Suurin osa tutkittavista (76\%) kertoi käyttävänsä mielellään sähköisiä sosiaali- ja terveydenhuollon palveluita. Lisäksi suurin osa vastaajista (76\%) luotti siihen, että he saavat hoidettua asiansa asioidessaan sähköisissä sosiaali- ja terveydenhuollon palveluissa. Ikäluokkien välillä ei ollut merkityksellisiä poikkeamia. Kysyttäessä, saavatko tutkittavat hoidettua asiat ylipäätään sähköisissä palveluissa, 78 prosenttia vastasi "kyllä". Tutkittavat kokivat sähköiset palvelut myös hyödyllisiksi. Väittämään "Sähköisten palveluiden käytöstä on minul- le hyötyä" 88 prosenttia vastasi "täysin samaa mieltä" tai "osittain samaa mieltä".

Sähköisten palveluiden käyttöä verrattiin perinteisiin lähipalveluihin kysymyksellä "Asioin mieluummin sähköisesti kuin henkilökohtaisesti?", jossa oli avoin vastausmahdollisuus. Suurimmiksi hyödyiksi koettiin sähköisten palveluiden tuoma ajansäästö ja paikkariippumattomuus. Vastaajat myös kokivat sähköisten palveluiden säästävän kustannuksia, koska heidän ei tarvitse lähteä palveluiden luo. Suurimmaksi käytön esteeksi koettiin toive tai tarve henkilökohtaiseen kontaktiin. Vastaajat kokivat, että henkilökohtaisessa asiakaspalvelussa myös asiat hoituvat paremmin ja samalla kertaa. Osa vastaajista koki, että he eivät osaa 
Taulukko 3. Sähköisten palveluiden käytön syyt ja esteet ikäluokittain $(n=283)$.

\begin{tabular}{|c|c|c|c|c|c|c|c|c|}
\hline \multirow[b]{2}{*}{$\begin{array}{l}\text { Syyt sähköisten palveluiden } \\
\text { käyttöön }\end{array}$} & \multicolumn{2}{|c|}{ 65-74-vuotiaat } & \multicolumn{2}{|c|}{ 75-84-vuotiaat } & \multicolumn{2}{|c|}{$\geq 85$-vuotiaat } & \multicolumn{2}{|c|}{ Kaikki ikäluokat } \\
\hline & lkm & $\%$ & lkm & $\%$ & $\mathrm{lkm}$ & $\%$ & lkm & $\%$ \\
\hline Ajansäästö & 38 & 19,7 & 21 & 25,0 & 0 & 0,0 & 59 & 20,8 \\
\hline Paikkariippumattomuus & 27 & 14,0 & 7 & 8,3 & 0 & 0,0 & 34 & 12,0 \\
\hline Kustannussäästöt & 5 & 2,6 & 3 & 3,6 & 2 & 33,3 & 10 & 3,5 \\
\hline Käytön helppous & 18 & 9,3 & 16 & 19,0 & 0 & 0,0 & 34 & 12,0 \\
\hline \multicolumn{9}{|l|}{$\begin{array}{l}\text { Syyt sähköisten palveluiden } \\
\text { käyttämättömyyteen }\end{array}$} \\
\hline $\begin{array}{l}\text { Tarve/toive } \\
\text { henkilökohtaiseen kontaktiin }\end{array}$ & 27 & 14,0 & 21 & 25,0 & 1 & 16,7 & 49 & 17,3 \\
\hline Asioiden hoituminen & 39 & 20,2 & 8 & 9,5 & 1 & 16,7 & 48 & 17,0 \\
\hline Osaamattomuus & 3 & 1,6 & 2 & 2,4 & o & 0,0 & 5 & 1,8 \\
\hline $\begin{array}{l}\text { Luottamattomuus } \\
\text { tietosuojaan tai sähköisiin } \\
\text { palveluihin }\end{array}$ & 36 & 18,7 & 6 & 7,1 & 2 & 33,3 & 44 & 15,5 \\
\hline
\end{tabular}

käyttää sähköisiä palveluita tai että he eivät luota niihin tai niiden tietosuojaan. Syitä sähköisten palveluiden käyttöön ja käyttämättömyyteen on esitelty taulukossa 3.

Tutkittavista 64 prosenttia oli asioinut aiemmin sähköisesti yksityisen palveluntuottajan kanssa ja 82 prosenttia julkisen palvelutuottajan kanssa. Vastaajista 45 prosenttia oli käyttänyt hyvin usein tai usein sähköisiä sosiaali- ja terveydenhuollon palveluita. Vastaajat luottivat siihen, että heidän tietonsa pysyvät turvassa. Vastaajista 81 prosenttia oli samaa mieltä ja 16 prosenttia eri mieltä väittämän "Luotan, että asioidessani sähköisesti tietoni pysyvät turvassa" kanssa.

\section{Pohdinta ja johtopäätökset}

Tutkimuksemme perusteella kyselyyn osallistuneilla 65-74-vuotiailla henkilöillä näyttäisi olevan halu ja valmius käyttää sosiaali- ja terveydenhuollon sähköisiä palveluita. Toisaalta tietotekniset taidot näyttävät heikentyvän vanhemmilla ikäluokilla. Yli 85-vuotiaiden osuus tutkimusaineistossa on merkittävän pieni, mikä voi olla seurausta heidän heikoista tietoteknisistä valmiuksistansa. Havaintomme on kuitenkin rohkaiseva, sillä aiempien kansainvälisten tutkimusten perusteella yli 63-vuotiailla on todettu olevan haasteita teknologian ja terveysteknologian käytössä (Kim 2009; Goodall ym. 2014; Lind \& Karlsson 2014). Sähköisten palveluiden käytön esteitä ovat olleet tarve henkilökohtaiseen kontaktiin tai se, ettei palveluita ole osattu käyttää. Aiempien tutkimusten mukaan ikääntyvällä väestöllä voi olla pelkoa teknologiaa kohtaan tai fyysisiä ja kognitiivisia rajoitteita käyttää sähköisiä palveluita (Kim ym. 2009; Goodall ym. 2014; Lind \& Karlsson 2014). Nämä aiempien tutkimusten havainnot toistuvat myös tässä tutkimuksessa, mutta silti enemmistö käyttää mielellään sähköisiä sosiaali- ja terveydenhuollon palveluita. Tutkimuksemme mukaan palveluiden käyttöönottoon kannustavat palveluiden tuoma ajansäästö ja paikkariippumattomuus. Sähköiset palvelut tuovat myös kustannussäästöjä esimerkiksi matkakustannusten jäädessä pois. Palvelut koettiin myös helppokäyttöisiksi. 
Maantieteellisten erojen ja taloudellisten tekijöiden tiedetään lisäävän niin sanottua digitaalista kuilua. Suurin vaikuttava tekijä digitaalisen kuilun syntyyn on se, että ikääntyvällä väestöllä ei ole taitoja tai välineitä käyttää sähköisiä palveluita. Myös ikääntymisen aiheuttama fyysisen tai kognitiivisen toimintakyvyn aleneminen voi aiheuttaa sen, ettei sähköisten palvelujen käytössä tarvittavia laitteita käytetä. (Rasmus 2010; Reiners ym. 2019.) Oma havaintomme on, että ikään liittyvä digitaalinen kuilu saattaa tulevaisuudessa pienentyä. Tutkimuksemme perusteella kyselyyn osallistuneilla 65-74-vuotiailla on riittävät tietotekniset taidot ja välineet käyttää sähköisiä palveluita. Tutkimuksemme aineistonkeruutavan aiheuttama mahdollinen vääristymä on kuitenkin otettava huomioon. Maantieteellisistä ja taloudellisista eroista huolimatta tutkittavilla on digitaalisten palveluiden käytössä tarvittavat laitteet. 65-74-vuotiaat tähän tutkimukseen osallistuneet käyttävät sähköisiä palveluita mielellään, ja he kokevat saavansa asiansa hoidettua palveluissa. Kotikunnan koolla näytti kuitenkin olevan vaikutusta sähköisen tiedonhaun määrään. Pienissä kunnissa asuvat hakivat enemmän lisätietoja sairauksiinsa kuin suurissa ja keskisuurissa kunnissa asuvat. Tämä voi olla seurausta pienempien kuntien perinteisten palveluiden saavuttamattomuudesta tai pitkistä välimatkoista.

Tutkimuksen otoksessa 65-74-vuotiaat edustivat suurinta osaa tutkittavista (78 \%). Tämä ikäryhmä koki tietotekniset taitonsa hyviksi, ja myös tämän perusteella voidaan sosiaali- ja terveydenhuollon palveluiden tarjoajia rohkaista suunnittelemaan palveluverkkojaan enemmän sähköisiksi erityisesti pienemmillä paikkakunnilla. Palveluverkkoja suunniteltaessa olisi otettava huomioon väestön mahdollisuus käyttää digitaalisia palveluita. Osa perinteisistä palveluista voidaan korvata sähköisillä vaihtoehdoilla. Sähköisten palveluiden on aiemmissa tutkimuksissa todettu tuovan kustannussäästöjä (Hyppönen ym. 2018a). Sähköisiä palveluita suunniteltaessa on kuitenkin otettava huo- mioon väestön vanhimmat ikäluokat, joiden tietotekniset taidot tai välineet eivät välttämättä ole riittävät.

Sähköistyvät palvelut vaativat myös uutta osaamista sosiaali- ja terveydenhuollon ammattilaisilta (Hyppönen ym. 2018b; Kinnunen ym. 2019). Myös terveydenhuollon ammattilaiset on syytä kouluttaa sähköisten palveluiden käyttöön, jotta väestön ohjaaminen palveluiden piiriin helpottuu. Näin on todettu myös Suomessa terveydenhuollon ammattilaisille tehdyssä tutkimuksessa (Kujala ym.2018).Huomiota on kiinnitettävä myös sähköisten palveluiden käyttäjäkokemukseen ja siihen, miten esimerkiksi näkövaikeudet vaikuttavat palveluiden käyttöön. Näihin aiheisiin perehdytään myöhemmin ilmestyvissä tutkimusartikkeleissa.

Aineistonkeruu toteutettiin harkitusti sähköisellä kyselyllä, jossa vastaukset annettiin anonyymisti ja vastaaminen oli vapaaehtoista. Tutkittaville lähetettiin kyselylinkin yhteydessä tiedote tutkimuksesta, jossa oli yhteystiedot mahdollisia kysymyksiä varten. Tämän tutkimuksen heikkoutena on aineistonkeruumenetelmä. Sähköinen kysely saattaa vääristää tutkimustuloksia, koska tietokonetta tai älylaitteita käyttämättömien ääni ei tule kuulluksi, joten tutkimuksen validiteetti saattaa kärsiä. Tutkimukseen oli mahdollista osallistua avustettuna. Näitä vastauksia tuli vain muutamia (13 kpl). Tutkimusasetelma vastaa tutkimuskysymyksiin vain tämän tutkimuksen otoksen osalta. Jatkossa on syytä tutkia myös sitä väestön osaa, jolla ei ole mahdollisuutta käyttää sähköisiä kanavia. Käytetty teoria ja siitä johdettu kyselylomake sopi tutkimukseen hyvin, kuten aiemmissa tutkimuksissa on todettu (Wills ym. 2008; Kijsanayotin ym. 2009). Tutkimuksessa käytetty UTAUT-malli pyrkii ennustamaan teknologian käyttöä käyttöaikomuksen perusteella. Käyttöaikomukseen vaikuttavat suorituskykyodotukset, vaivattomuusodotukset, sosiaaliset vaikutukset ja mahdollistavat odotukset (Venkatesh ym. 2003). Tutkimuksemme perusteella teknologian käytön mahdollistavat olosuhteet ovat hyvät. Tutki- 
mukseen osallistuneilla 65-74-vuotiailla on tarvittavat välineet ja taito käyttää järjestelmiä. Vaivattomuusodotukset täyttyvät myös, koska tutkittavat kokevat sähköisten palveluiden käytön helpoksi ja mielekkääksi. Suorituskykyodotukset täyttyvät, koska tutkittavien mielestä sähköisten palveluiden käyttö tuo heille hyötyjä esimerkiksi ajansäästönä.

\section{Kirjallisuus}

Goodall K, Newman L, Ward P. Improving access to health information for older migrants by using grounded theory and social network analysis to understand their information behaviour and digital technology use. Eur J Cancer Care 2014;23(6):728-38.

https://doi.org/10.1111/ecc.12241

Hoque R, Sorwar G. Understanding factors influencing the adoption of mHealth by the elderly: an extension of the UTAUT model. Int J Med Inform 2017;101:75-84.

https://doi.org/10.1016/j.ijmedinf.2017.02.002

Hyppönen H, Ilmarinen K. Sosiaali- ja terveydenhuollon digitalisaatio. Suomen sosiaalinen tila 2/2016. Terveyden ja hyvinvoinnin laitos, 2016. Internet: http://www.julkari.fi/bitstream/handle/10024/131301/URN_ISBN_978-952-302739-8.pdf? sequence=1 (viitattu 2.6.2019).

Hyppönen H, Lääveri T, Hahtela N, Suutarla A, Sillanpää K, Kinnunen UM ym. Kyvykkäille käyttäjille fiksut järjestelmät? Sairaanhoitajien arviot potilastietojärjestelmistä 2017. Finnish Journal of eHealth and eWelfare 2018a;10(1):30-59.

Hyppönen H, Pentala-Nikulainen O, Aalto A. Sosiaali- ja terveydenhuollon sähköinen asiointi 2017. Kansalaisten kokemukset ja tarpeet. $\mathrm{Ra}^{-}$ portti 3/2018. Terveyden ja hyvinvoinnin laitos, 2018b. Internet: http://www.julkari.fi/bitstream/ handle/10024/136258/URN_ISBN_978-952343-103-4.pdf ? sequence $=1 \&$ is Allowed=y $\quad$ (viitattu 16.4.2019).

Kauppila T, Kiiski K, Lehtonen M. Sähköhelmenkalastus: sosiaalihuollon sähköisten palvelujen nykytila ja kehittämistarpeet. Sosiaali- ja terveysministeriön raportteja ja muistioita 14/2018. Internet: http://julkaisut.valtioneuvosto.fi/bitstream/ handle/10024/160653/STM_rap_14_2018.pdf (viitattu 3.6.2019).
Sosiaalisesta näkökulmasta käytön vapaaehtoisuus on etu.

\section{Yhteydenotto:}

Jukka Mielonen, YtM, väitöskirjatutkija

Sosiaali- ja terveysjohtamisen laitos

Yhteiskuntatieteiden ja kauppatieteiden tiedekunta Itä-Suomen yliopisto

jukmi@student.uef.fi

Kijsanayotin B, Pannarunothai S, Speedie SM. Factors influencing health information technology adoption in Thailand's community health centers: applying the UTAUT model. Int J Med Inform 2009;78(6):404-16. https://doi.org/10.1016/j.ijmedinf.2008.12.005

Kim E, Stolyar A, Lober W, Herbaugh A, Shinstrom $\mathrm{S}$, Zierler B ym. Challenges to using an electronic personal health record by a low-income elderly population. J Med Internet Res. 2009; 11(4):e44. Kinnunen UM, Heponiemi T, Rajalahti E, Ahonen O, Korhonen T, Hyppönen H. Factors related to health informatics competencies for nurses - Results of a national electronic health record survey. Comput Inform Nurs 2019;37(8):420-9. https://doi.org/10.1097/cin.0000000000000511 Kujala S, Rajalahti E, Heponiemi T, Hilama P. Health professionals' expanding eHealth competences for supporting patients' self-management. Stud Health Technol Inform 2018;247:181-5.

Lind L, Karlsson D. Telehealth for "the digital illiterate" - Elderly heart failure patients' experiences. Stud Health Technol Inform 2014;205:353-7.

Mantere J. WWW-palvelun käyttäjäkeskeinen suunnittelu ikääntyneille käyttäjille. Teknillinen korkeakoulu, 2001.

OECD. Understanding the digital divide. OECD publications, 2001. Internet: https://www. oecd-ilibrary.org/science-and-technology/understanding-the-digital-divide_236405667766 (viitattu 25.1.2020).

Pääministeri Antti Rinteen hallituksen ohjelma 6.6.2019. Osallistava ja osaava Suomi - sosiaalisesti, taloudellisesti ja ekologisesti kestävä yhteiskunta. Valtioneuvoston julkaisuja 2019:23. Internet: http://urn.fi/URN:ISBN:978-952-287-756-7 (viitattu 23.9.2019). 
Rasmus A. Kansalaisten sähköinen asiointi viranomaistoiminnassa - Haasteena digitaalinen kuilu. Tietojärjestelmätieteen kandidaatintutkielma. Jyväskylän yliopisto, Tietojenkäsittelytieteiden laitos, 2010.

Reiners F, Sturm J, Bouw LJW, Wouters EJM. Sociodemographic factors influencing the use of ehealth in people with chronic diseases. Int J Environ Res Public Health. 2019 Feb 21;16(4):645. https://dx.doi.org/10.3390/ijerph16040645

Rosenlund M, Kinnunen UM. Ikäihmisten kokemukset terveydenhuollon sähköisten palvelujen käytöstä ja kokemusten hyödyntäminen palvelujen kehittämisessä - kuvaileva kirjallisuuskatsaus. Finnish Journal of eHealth and eWelfare 2018;10(2-3):264-284. https://doi.org/10.23996/fjhw.69136

Saarikoski P. Koneen lumo: mikrotietokoneharrastus Suomessa 1970-luvulta 1990-luvun puoliväliin. Nykykulttuurin tutkimuskeskuksen julkaisuja, 2004. Internet: https://jyx.jyu.fi/handle/123456789/55764\# (viitattu 15.4.2019).

Seppälä A, Puranen K. Sote-tieto hyötykäyttöön 2020 strategian väliarviointi: Loppuraportti
14.11.2018. Sosiaali- ja terveysministeriön raportteja ja muistioita 2019:1. Helsinki: Sosiaalija terveysministeriö, 2019. Internet: http://urn.fi/URN:ISBN:978-952-00-4023-9 (viitattu 12.8.2019).

Tilastokeskus. Suomen virallinen tilasto (SVT): Väestörakenne. Helsinki: Tilastokeskus, 2019. Internet: http://www.stat.fi/til/vaerak/index.html (viitattu 2.12.2019).

Valvira. Terveydenhuollon laitteet ja tarvikkeet. 2017. Internet:

https://www.valvira.fi/terveydenhuolto/terveysteknologia/tuotteen_markkinoille_saattaminen/ terveydenhuollon_laitteet_ja_tarvikkeet (viitattu 25.1.2020).

Venkatesh V, Morris MG, Davis GB, Davis FD. User acceptance of information technology: Toward a unified view. MIS Quarterly 2003;27(3):42578. https://doi.org/10.2307/30036540

Wills MJ, El-Gayar OF, Bennett D. Examining healthcare professionals' acceptance of electronic medical records using UTAUT. Issues in Information Systems 2008;10(2):396-401. 